\title{
Adipose-derived stem cells ameliorate atopic dermatitis by suppressing the IL-17 expression of Th17 cells in an ovalbumin-induced mouse model
}

\author{
Jingyan Guan, Yibao Li, Feng Lu* and Jingwei Feng ${ }^{*}$
}

\begin{abstract}
Background: Mesenchymal stem cells (MSCs) have therapeutic potential for atopic dermatitis (AD) owing to their immunoregulatory effects. However, the underlying mechanisms associated with the therapeutic efficacy of MSCs on $\mathrm{AD}$ are diverse and related to both cell type and delivery method.

Objectives: This study investigated the therapeutic effect and mechanisms of adipose-derived stem cells (ADSCs) on AD using an ovalbumin (OVA)-induced AD mouse model.

Methods: AD mice were subcutaneously injected with mouse ADSCs, cortisone, or PBS, and the therapeutic effects were determined by gross and histological examinations and serum lgE levels. Additionally, GPCR, RNA-sequencing analyses of skin samples and co-culture of ADSCs and Th17 cells were conducted to explore the underlying therapeutic mechanisms.

Results: ADSCs treatment attenuated the AD pathology, decreased the serum lgE levels, and decreased mast cells infiltration in the skin of the model mice. Moreover, tissue levels of IL-4R and Th17-relevant products (IL-17A, CCL20, and MMP12) were suppressed in the ADSC- and cortisone-treated groups. Genomics and bioinformatics analyses demonstrated significant enrichment of inflammation-related pathways in the downregulated genes of the ADSCand cortisone-treated groups, specifically the IL-17 signaling pathway. Co-culture experiments revealed that ADSCs significantly suppressed the proliferation of Th17 cells and the expression of proinflammatory cytokines (IL-17A and RORYT). Furthermore, expression levels of PD-L1,TGF- $\beta$, and PGE2 were significantly upregulated in co-cultured ADSCs relative to those in monocultured ADSCs.
\end{abstract}

Conclusion: ADSCs ameliorate OVA-induced AD in mice mainly by downregulating IL-17 secretion of Th17 cells. Keywords: Adipose-derived stem cells, Atopic dermatitis, IL-17 signaling pathway, Th17 cells, Ovalbumin, Mouse model

*Correspondence: doctorlufeng@hotmail.com; 15816703@qq.com Department of Plastic and Cosmetic Surgery, Nanfang Hospital, Southern Medical University, 1838 Guangzhou North Road, Guangzhou 510515, Guangdong, People's Republic of China

\section{Background}

Atopic dermatitis (AD), also known as atopic eczema, is a chronic and recurrent skin disease that affects up to $20 \%$ of children and $10 \%$ of adults worldwide and significantly reduces the quality of life for affected individuals [1-4]. Currently, major risk factors for $\mathrm{AD}$ are considered to be genetic predisposition (e.g., genetic mutations in the permits use, sharing, adaptation, distribution and reproduction in any medium or format, as long as you give appropriate credit to the original author(s) and the source, provide a link to the Creative Commons licence, and indicate if changes were made. The images or other third party material in this article are included in the article's Creative Commons licence, unless indicated otherwise in a credit line to the material. If material is not included in the article's Creative Commons licence and your intended use is not permitted by statutory regulation or exceeds the permitted use, you will need to obtain permission directly from the copyright holder. To view a copy of this licence, visit http://creativecommons.org/licenses/by/4.0/. The Creative Commons Public Domain Dedication waiver (http://creativeco mmons.org/publicdomain/zero/1.0/) applies to the data made available in this article, unless otherwise stated in a credit line to the data. 
filaggrin gene $[5,6]$ ) and environmental factors (e.g., air pollution [7], diet [8], and stress [9]). AD pathophysiology involves a complex interaction between epidermal barrier disruption, immune dysregulation, and skin microbiome abnormality [10]. Although these dysfunctions form an inseparable vicious circle, it has been considered that dysregulation of helper $\mathrm{T}$ (Th) cell immune responses plays a central role in $\mathrm{AD}$ pathogenesis and development, especially in Th2 immune responses [11]. Recent studies have demonstrated that in addition to classical Th2, other subsets of Th cells also contribute to the $\mathrm{AD}$ pathogenesis (e.g., Th1, Th17, and Th22) [12, 13]. Therefore, treatments that reduce the $\mathrm{Th}$-mediated immune response have been the mainstream therapeutic methods for AD [14]. These treatments include nonspecific anti-inflammatory and immunosuppressive drugs, such as corticosteroids, calcineurin inhibitors, leukotriene receptor antagonists, and antihistamines. However, these drugs only provide temporary and limited symptom relief. Additionally, some are associated with adverse effects and drug resistance following long-term treatment $[15,16]$. In recent years, significant progress has been made toward increasing our understanding of $\mathrm{AD}$ pathogenesis, and the development of novel therapies that are safe and effective for AD has been intensely pursued.

Mesenchymal stem cells (MSCs) are a promising cellbased treatment option for AD due to their unique tissue regenerative capacity and immunomodulatory ability $[17$, 18]. In general, MSCs can be extracted from multiple tissues, such as bone marrow, umbilical cord, adipose tissue, and dental pulp, among others [19]. Compared with other types of MSCs, adipose-derived stem cells (ADSCs) have several advantages. In particular, adipose tissue can be readily obtained through liposuction with a small incision, and ADSCs can be isolated in large amounts via relatively simple procedures. In the previous decade, several preclinical studies reported the use of ADSCs to treat AD [20-22], with these studies demonstrating ADSC-based cytotherapy as a promising method for $\mathrm{AD}$ treatment according to therapeutic mechanisms mainly attributed to the paracrine effect of the administered cells. Despite the encouraging results, these studies failed to comprehensively analyze the complex pathogenesis of $\mathrm{AD}$ and the mechanism of interaction between MSCs and AD pathogenesis-related immune cells. Moreover, the therapeutic potential of ADSCs may vary depending on the animal model, cell type, and the routine of administration, among others [20, 23-25]. Therefore, further investigation is needed to elucidate the specific mechanisms associated with ADSC-specific treatment of AD.

This study aimed to provide insight into the pathological changes that occur in AD skin and broaden the understanding of the therapeutic effect of ADSCs on
$\mathrm{AD}$ pathogenesis. Ovalbumin (OVA)-induced $\mathrm{AD}$ mice were employed as a model, with these mice subcutaneously administered with mouse ADSCs and evaluated for changes in clinical severity, histological signatures of $\mathrm{AD}$, and serum immunoglobulin E (IgE) levels. Additionally, this study used high-throughput RNA-sequencing analysis to investigate the therapeutic mechanisms of ADSCs on $\mathrm{AD}$ and identified the interleukin (IL)-17 signaling as a possible target of ADSC-specific effects. Furthermore, the underlying mechanism of the anti-atopic effect of ADSCs was investigated by in vitro co-culture of ADSCs with Th17 cells, and the pivotal cytokines in relation to cellular interactions were also explored.

\section{Materials and methods \\ Animals}

All animal procedures were approved by the Institutional Animal Care and Use Committee of Nanfang Hospital (No. NFYY-2020-0294), and all operations were performed in accordance with the National Health and Medical Research Council (People's Republic of China) guidelines. All surgical procedures were performed according to the aseptic principle.

\section{Isolation and culture of mouse ADSCs}

ADSC isolation was performed as previously described [26]. Female BALB/c mice ( 6 weeks old, $n=6$ ) were purchased from Nanfang Hospital Animal Center (Guangzhou, China). After shaving, mice were sacrificed, and subcutaneous fat was harvested. Approximately $1.5 \mathrm{~g}$ of fat was acquired from each mouse and stored in a sterile 50-ml centrifuge tube. Subsequently, red blood cells were removed by washing three times with phosphate-buffered saline (PBS; pH 7.4), and the isolated fat was cut into small pieces, after which it was digested with $0.2 \%$ type I collagenase (Sigma-Aldrich, St. Louis, MO, USA) for $45 \mathrm{~min}$ at $37^{\circ} \mathrm{C}$ with continuous stirring. After digestion, the stromal vascular fraction (SVF) was separated from the adipose tissue by centrifugation $(200 g, 5 \mathrm{~min})$, resuspended with PBS, and filtered to remove large debris. The SVF suspension then underwent an additional round of centrifugation (200g, $5 \mathrm{~min}$ ), followed by resuspension in a complete growth medium comprising Dulbecco's modified Eagle's medium (DMEM)-low glucose (Gibco-BRL, Carlsbad Island, NY, USA) supplemented with $10 \%$ fetal bovine serum (FBS; Gibco-BRL, Carlsbad Island, NY, USA) and $1 \%$ penicillin/streptomycin (DMEM-low glucose+; Gibco-BRL, Carlsbad Island, NY, USA). The SVF suspension was then placed in T75 cell culture flasks at a density of approximately $5 \times 10^{5}$ cells/flask (P0) and incubated at $37{ }^{\circ} \mathrm{C}$ with $5 \%$ carbon dioxide $\left(\mathrm{CO}_{2}\right)$ and $95 \%$ humidity. The medium was changed every 3 days, and cells were passaged at $90 \%$ confluence. ADSCs within the 
range of passage 3 to passage 5 were used for subcutaneous injection.

\section{In vitro differentiation of ADSCs}

To analyze cell differentiation potential, the chondrogenic, osteogenic, and adipogenic differentiations of ADSCs were induced as described previously [27]. For chondrogenic differentiation, ADSCs were cultured in a chondrogenic medium (Cyagen Biosciences, Santa Clara, CA, USA) for 4 weeks. For osteogenic differentiation, ADSCs were cultured in an osteogenic medium (Cyagen Biosciences, Santa Clare, CA, USA) for 4 weeks. For adipogenic differentiation, ADSCs were cultured in an adipogenic medium (Cyagen Biosciences, Santa Clara, CA, USA) for 2 weeks. All cells were incubated at $37{ }^{\circ} \mathrm{C}$ with $5 \% \mathrm{CO}_{2}$ and $95 \%$ humidity. Corresponding mediums were changed every 3 days. After induction, the cells were fixed in $4 \%$ paraformaldehyde solution and assessed by Alcian Blue, Alizarin Red, and Oil Red O staining (Cyagen Biosciences, Santa Clara, CA, USA), respectively.

\section{Murine model of AD}

Female BALB/c mice (6-weeks old, $n=24$ ) were randomly divided into 4 groups ( $n=6$ per group) as follows: (1) untreated mice (normal control); (2) OVA-sensitized and PBS-treated mice (PBS group); (3) OVA-sensitized and ADSC-treated mice (ADSC group); and (4) OVAsensitized and cortisone cream-treated mice (cortisone group). Mice were housed at $25{ }^{\circ} \mathrm{C}$ under pathogen-free conditions, with a 12-/12-h light/dark cycle and ad libitum access to food and water.

The murine model of $\mathrm{AD}$ was prepared as described previously [28]. Briefly, all mice (except for those in the normal control group) were anesthetized with isoflurane, and their dorsal skin was shaved, followed by applying 3 M tape (Tegaderm; Owens and Minor, Mechanicsville, VA, USA) stripped six times. Subsequently, each mouse was sensitized with a sterile patch soaked with $100 \mu \mathrm{l}$ of $100 \mu \mathrm{g}$ OVA (Sigma-Aldrich, St. Louis, MO, USA). The patch was placed on the dorsal skin of each mouse and changed daily for 1 week. Each mouse was exposed to a total of three 1-week sensitizations, with 2 -week intervals. On days 28,35 , and 42 of OVA sensitization and challenge, $1 \mathrm{ml}$ of ADSCs suspension $\left(1 \times 10^{6}\right)$ was subcutaneously injected into nine sites in the area covered by the OVA patches on the dorsum of mice in the ADSC group (Fig. 1a). As a negative control, PBS group mice were subcutaneously injected with $1 \mathrm{ml}$ PBS in the same area and at the same time points. In the cortisone group, $0.1 \mathrm{~g}$ of cortisone cream (Dinuo Pharmaceutical Co., Ltd., Hunan, China) was daubed on the dorsal skin of each mouse at the same time points and area as a positive control. All mice were sacrificed on day 50, with half of the sensitized dorsal skin fixed in 10\% formalin and the other half stored at $-80^{\circ} \mathrm{C}$ for further analysis.

\section{Measurement of clinical severity}

The severity of dorsal skin lesion was assessed according to six symptoms described in a previous study [21]: erythema/hemorrhage, oozing/crust, erosion/excoriation, swelling/edema, lichenification, and dryness. Symptom scores of 0 to 3 (none to severe) were applied by two independent investigators, with the sum of these scores defined as the clinical severity (scale $0-18$ ).

\section{Histologic examination}

For histologic analyses, skin samples were obtained from the dorsal skins of mice in the four groups on day 50 (24 h after patch removal). Skin samples were fixed in $10 \%$ formalin for at least $24 \mathrm{~h}$ and then embedded in paraffin and cut into $4 \mu \mathrm{m}$ sections for hematoxylin and eosin (H\&E) staining or Toluidine Blue (TB) staining. A microscope (Olympus Corp., Tokyo, Japan) was used to obtain photomicrographs (magnification; $\times 200$ ), and 10 H\&E-stained regions for each group were selected randomly for epidermal thickness measurement using the Image s software (NIH, Bethesda, MD, USA). Infiltrated mast cells were counted in 10 random TB-stained regions for each group.

\section{Measurement of serum IgE levels}

On day 50, whole blood samples of mice were collected by removing the eyeballs after anesthesia. After clotting at $25{ }^{\circ} \mathrm{C}$ for $30 \mathrm{~min}$, the blood samples were centrifuged at $1000 \mathrm{~g}$ for $10 \mathrm{~min}$ at $4{ }^{\circ} \mathrm{C}$ and serum was collected and preserved at $-80^{\circ} \mathrm{C}$ until use. Serum IgE was detected using a mouse IgE enzyme-linked immunosorbent assay kit (Invitrogen, Carlsbad, CA, USA) according to the manufacturer instructions.

\section{RNA-sequencing analysis}

Total RNA was extracted from dorsal skin samples of the 4 groups ( $n=3$ per group) using TRIzol reagent (Invitrogen, Carlsbad, CA, USA) according to the manufacturer's instructions. RNA quantification was performed using Quant-IT RiboGreen (Invitrogen, Carlsbad, CA, USA) and RNA quality was assessed using the Bioanalyzer 2100 system (Agilent Technologies, Santa Clara, CA, USA). After quality inspection, mRNAs were purified, fragmented, and converted to first-strand complementary DNA (cDNA) via reverse transcription. The first-strand cDNA was subsequently converted to the second strand, followed by use of the AMPure XP system (Beckman Coulter, Miami, FL, USA) to purify the library fragments and screen 370- to 420-bp cDNA fragments. After library construction, polymerase chain reaction 


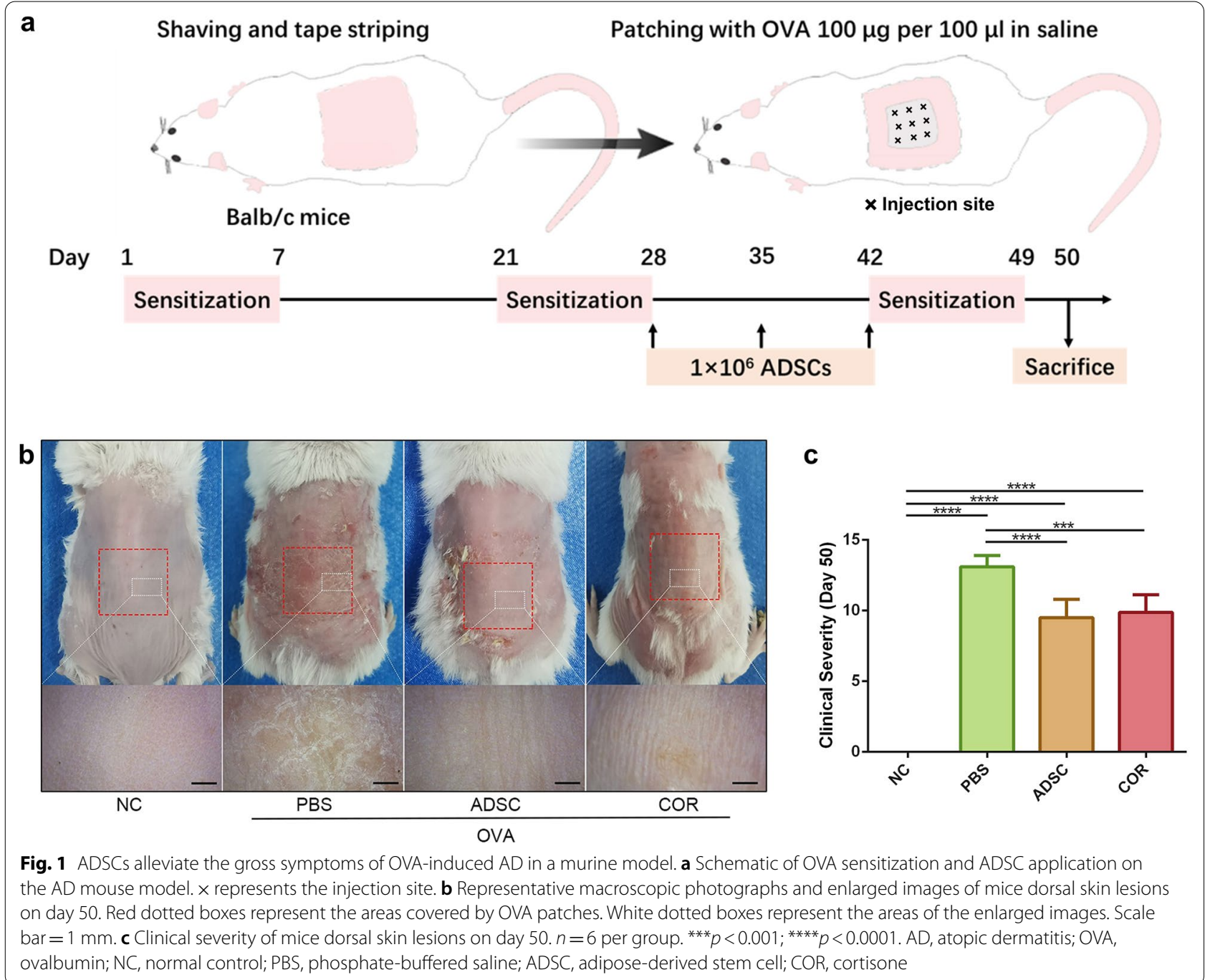

(PCR) was performed, with the products purified and verified using the AMPure XP (Beckman Coulter, Miami, FL, USA) and Agilent Bioanalyzer 2100 systems, respectively. A cluster of the index-coded samples was generated using a TruSeq PE cluster kit (v3-cBot-HS; Illumina, San Diego, CA, USA) on a cBot cluster generation system according to the manufacturer instructions. The Illumina Hiseq 3000 (Illumina, San Diego, CA, USA) was used to sequence the prepared libraries in a 150 -bp paired-end reads to generate raw reads. Using in-house Perl scripts, raw reads in the fastq format were processed into clean reads and then aligned to the reference genome sequence of Mus musculus (mm10) using Hisat2 (v2.0.5). The read numbers of the genes in each group were calculated using FeatureCounts (v1.5.0-p3). R software was used for quantile normalization and subsequent data processing, and differentially expressed genes (DEGs) between each group were identified using the DESeq2 $R$ package (v1.20.0) with a significance threshold of $\mid \log 2$ fold change (FC) $\mid \geq 1$ and an adjusted $p$ (padj) $\leq 0.05$. The ClusterProfiler $\mathrm{R}$ software package was used for Gene Ontology (GO) enrichment analysis and Kyoto Encyclopedia of Gene and Genome (KEGG) enrichment analysis. GO terms and KEGG pathways with a padj $\leq 0.05$ were considered significantly enriched.

\section{Isolation of naïve mouse CD4+T cells and in vitro differentiation into Th17 cells}

The isolation of naive mouse CD4+ T cells was performed as described previously [29]. Briefly, the spleens and lymph nodes of BALB/c female mice (5-10-weeks old) were obtained under aseptic conditions. These two tissues were then placed in PBS supplemented with $1 \%$ penicillin/streptomycin (PBS+), followed by grinding into a suspension using two slides. After filtration through a $120 \mu \mathrm{m}$ pore size 
nylon mesh (Corning Costar, Cambridge, MA, USA), the suspension was replenished using PBS+ and centrifuged at $475 \mathrm{~g}$ and $4{ }^{\circ} \mathrm{C}$ for $5 \mathrm{~min}$. The lymph node cell pellet was resuspended with $2 \mathrm{ml} \mathrm{PBS+}$, and the splenic cell pellet was resuspended with ammoniumchloride-potassium lysis buffer (1 $\mathrm{ml}$ per spleen) for $1 \mathrm{~min}$ to lyse red blood cells. Then, $10 \mathrm{ml}$ of PBS+ was added and centrifugated at $475 \mathrm{~g}$ and $4{ }^{\circ} \mathrm{C}$ for $5 \mathrm{~min}$. The splenic cell pellet was resuspended again with $10 \mathrm{ml} \mathrm{PBS}+$ and mixed with the lymph node cell suspension. After a final round of centrifugation at $475 \mathrm{~g}$ and $4{ }^{\circ} \mathrm{C}$ for $5 \mathrm{~min}$, the combined cell pellet was subjected to CD4 enrichment using $\mathrm{T}$ cell enrichment columns (R\&D Systems, Minneapolis, MN, USA). Mouse $\mathrm{CD} 4+\mathrm{T}$ cell isolation kits (Miltenyi Biotec $\mathrm{GmbH}$, Bergisch Gladbach, Germany) were used to purify naive $\mathrm{CD} 4+\mathrm{T}$ cells through negative selection according to manufacturer instructions.

For in vitro differentiation, naive $\mathrm{CD} 4+\mathrm{T}$ cells were placed in a 6-well plate coated with anti-CD3 and antiCD28 $(2 \mu \mathrm{g} / \mathrm{ml})$ antibodies. The cells were cultured in Roswell Park Memorial Institute (RPMI)-1640 (GibcoBRL, Carlsbad Island, NY, USA) supplemented with 10\% FBS, $2 \mathrm{mM}$ L-glutamine, $1 \%$ penicillin/streptomycin (RPMI-1640+), and Th17 polarizing cytokines $[10 \mathrm{ng} / \mathrm{ml}$ transforming growth factor-beta (TGF- $\beta$ ), $20 \mathrm{ng} / \mathrm{ml} \mathrm{IL-6,} 10 \mu \mathrm{g} / \mathrm{ml}$ anti-IL-4 antibody, and $10 \mu \mathrm{g} /$ $\mathrm{ml}$ anti-interferon-gamma (IFN- $\gamma$ ) antibody]. The cells were incubated at $37{ }^{\circ} \mathrm{C}$ with $5 \% \mathrm{CO}_{2}$ and $95 \%$ humidity for 4 to 5 days. On day 3 , cells were removed to uncoated new wells and cultured in RPMI-1640+ supplemented with $10 \mathrm{ng} / \mathrm{ml} \mathrm{IL-2} \mathrm{in} \mathrm{order} \mathrm{to} \mathrm{enhance}$ proliferation. All cytokines and antibodies applied for differentiation of $\mathrm{CD} 4+\mathrm{T}$ cells were purchased from BD Biosciences (San Diego, CA, USA).

\section{Co-culture of ADSCs and Th17 cells}

The co-culture experiment comprised three groups: direct co-culture of ADSCs and Th17 cells (experimental group) and monoculture of Th17 cells or ADSCs (two control groups). For the co-culture group, $1 \times 10^{5}$ ADSCs were placed into a 6-well plate and cultured overnight in $2 \mathrm{ml}$ DMEM-low glucose+until cells became adherent. The medium was then changed to $5 \mathrm{ml}$ RPMI-1640+, and Th17 cells $\left(2 \times 10^{6}\right.$ cells/well $)$ were added to obtain a ratio of 20:1 with the ADSCs. For the monoculture of Th17 cells, an equal number of Th17 cells were added to a blank well and cultured with $5 \mathrm{ml} \mathrm{RPMI}-1640+$. For the monoculture of ADSCs, $1 \times 10^{5}$ ADSCs were placed into another blank well and cultured with $5 \mathrm{ml}$ DMEM-low glucose+. The ADSCs and Th17 cells of each group were collected after $72 \mathrm{~h}$ of culture for further experiments.

\section{Quantitative real-time PCR (qPCR)}

The total RNA was extracted from the skin samples and cell samples with Trizol Reagent (Invitrogen, Carlsbad, CA, USA), followed by reverse transcription into cDNA using a reverse transcription kit (DBI Bioscience, Hennigsdorf, Germany) according to the manufacturer instructions. FastStart Universal SYBR Green Master (Cat No. 04913850001; Roche, Basel, Switzerland) was used to perform qPCR. The skin samples were tested for the following genes: IL-13, IL-4, IL-4 receptor (IL-4R), IL-17A, C-C motif chemokine ligand 20 (CCL20), matrix metallopeptidase 12 (MMP12), IFN- $\gamma$, and tumor necrosis factor-alpha (TNF- $\alpha)$. Th17 cell samples were tested for IL-17A, IL-17F, and RAR-related orphan receptor gamma $\mathrm{T}$ (ROR $\mathrm{T}$ ) and ADSC samples were tested for programed death ligand 1 (PD-L1), TGF- $\beta$, and prostaglandin E2 (PGE2). The primer-probe sequences for the genes are shown in Additional file 1: Table S1. Relative expression was determined using the $2^{-\Delta \Delta \mathrm{Ct}}$ method, and $\beta$-actin was used as an endogenous reference gene.

\section{Statistical analysis}

For RNA-sequencing analysis, statistical analysis was implemented using R software (www.r-project.org), and $\mathrm{R}$ packages were acquired on Bioconductor (www.bioco nductor.org). DEGs between each group were identified using Student's $t$ test, with significant differences in relative expression levels determined according to a $\left|\log _{2} \mathrm{FC}\right| \geq 1$ and padj $\leq 0.05$. Significantly enriched GO terms and KEGG pathways were identified using the ClusterProfiler $R$ package with a padj value was calculated using right-sided hypergeometric tests (padj $\leq 0.05$ was considered statistically significant). For the other experiments, data were presented as the mean \pm standard deviation (SD) and analyzed using SPSS (version 21.0; IBM Corp., Armonk, N.Y., USA). One-way analysis of variance, followed by the Tukey's multiple comparison test was utilized for multiple groups. An unpaired Student's $t$ tests was used to compare data between two groups. A $p \leq 0.05$ was considered statistically significant.

\section{Results}

\section{ADSCs exhibit multipotency}

The extracted ADSCs from passage 3 to 5 were subjected to chondrogenic, osteogenic, and adipogenic differentiation in vitro to test their multi-lineage differentiation potential. Cartilage glycosaminoglycans, calcium phosphates, and lipid drops produced by chondrocytes, osteocytes, and adipocytes were successfully 
detected by Alcian Blue (Additional file 2: Fig. S1a, red arrows), Alizarin Red (Additional file 2: Fig. S1b, yellow arrows), and Oil Red O (Additional file 2: Fig. S1c, white arrows) staining, respectively. These results indicated that the extracted ADSCs possessed multi-lineage differentiation potency.

\section{ADSCs ameliorate AD symptoms in an OVA-induced mouse model}

The therapeutic effect of ADSCs on AD was evaluated in an AD mouse model. On day 50, serious erythema and dryness, accompanied by lichenification and excoriation, were observed on the dorsal skins of PBS-treated mice; however, skin lesions were significantly improved (only slight skin redness) in the OVA-sensitized area of the mice in the ADSC- and cortisone-treated groups (Fig. 1b). Similarly, the clinical severity of the dorsal skin lesions was significantly lower in groups treated with ADSCs $(9.500 \pm 1.309$, $p<0.0001)$ and cortisone $(9.875 \pm 1.246, p<0.001)$ on day 50 as compared with that in mice treated with PBS (13.11 \pm 0.7817$)$ (Fig. 1c).

\section{ADSCs suppress epidermal thickening, mast cells infiltration, and serum IgE levels in an OVA-induced mouse model}

To determine the impact of ADSCs on the structure of $\mathrm{AD}$ skin, $\mathrm{H} \& \mathrm{E}$ staining was performed to evaluate changes in epidermal thickness. H\&E staining showed that the epidermis of the dorsal skin in PBS-treated mice exhibited remarkable thickening $(66.80 \pm 15.44 \mu \mathrm{m}$, $p<0.0001)$ as compared with that in normal control $(16.51 \pm 3.161 \mu \mathrm{m})$, whereas epidermal thickness was significantly lower in the ADSC-treated mice $(29.97 \pm 13.68 \mu \mathrm{m}, p<0.0001)$ and the cortisone-treated group $(36.39 \pm 18.89 \mu \mathrm{m}, p<0.0001)$ relative to the PBStreated group. Additionally, epidermal thicknesses in the ADSC group was slightly lower than that in the cortisone group $(p=0.0081)$, with no statistical difference relative
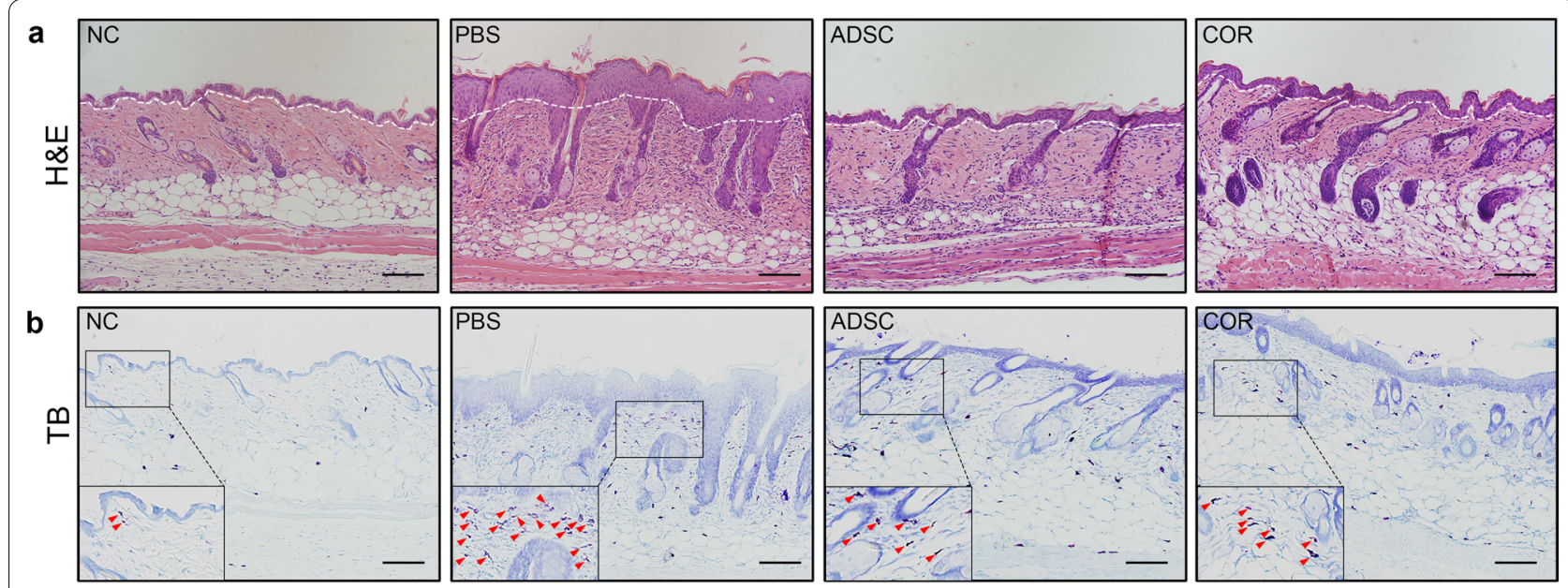

C

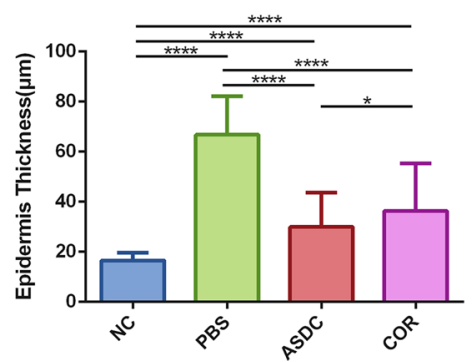

d

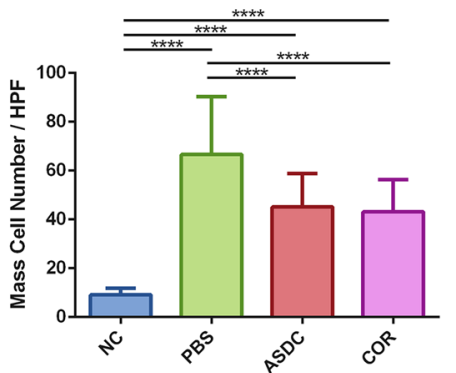

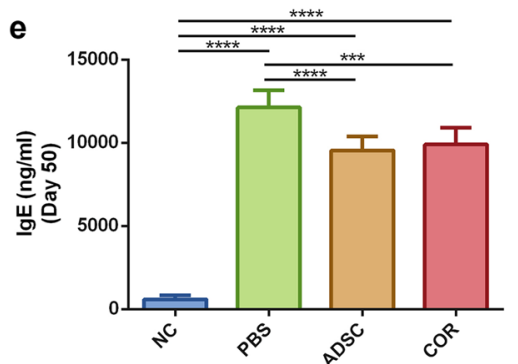

Fig. 2 ADSCs improve histological features of lesion sites and decrease serum lgE levels in mice with OVA-induced AD. a Representative H\&E staining photomicrographs of dorsal skin samples from the four groups. The epidermis and dermis are distinguished by white dotted lines, with the parts above the white dotted line representing the epidermal layer. Scale bar $=100 \mu \mathrm{m}$. b Representative TB staining photomicrographs of dorsal skin samples from the four groups. Red arrows show infiltrated mast cells. Scale bar $=100 \mu \mathrm{m}$. c Measurement of epidermal thickness in skin samples; $n=10$ per group. $\mathbf{d}$ Measurement of infiltrated mast cells in skin samples; $n=10$ per group. e Serum IgE level on day $50 ; n=6$ per group. ${ }^{*} p<0.05 ;{ }^{* * *} p<0.0001$. Scale bar $=100 \mu \mathrm{m}$. NC, normal control; PBS, phosphate-buffered saline; ADSC, adipose-derived stem cell; COR, cortisone; IgE, immunoglobulin E; AD, atopic dermatitis; OVA, ovalbumin; TB, Toluidine Blue 
to the normal control (Fig. 2a, c). Toluidine Blue staining is a useful method for identifying mast cells. Numerous bluish purple-stained mast cells were observed in the skin of the PBS-treated mice, whereas fewer infiltrated mast cells were found in the skin of the ADSC- and cortisonetreated mice (Fig. 2b, red arrow heads). Semi-quantification analysis showed that the numbers of infiltrated mast cells in the skin of both ADSC- $(45.11 \pm 13.76, p<0.0001)$ and cortisone-treated mice $(43.09 \pm 13.30, p<0.0001)$ were significantly lower than those in the PBS-treated mice $(66.60 \pm 23.77)$ (Fig. 2d). In parallel, a significant increase in the serum IgE levels were observed in PBStreated mice $(12,127 \pm 421.3 \mathrm{ng} / \mathrm{ml}, p<0.0001)$ as compared with those in the normal control $(598.8 \pm 245.5 \mathrm{ng} /$ $\mathrm{ml}$ ) on day 50 . By contrast, serum IgE levels were reduced in mice that received the ADSCs $(9547 \pm 832.1 \mathrm{ng} / \mathrm{ml}$, $p<0.0001)$ or cortisone treatment $(9903 \pm 1014 \mathrm{ng} / \mathrm{ml}$, $p<0.001$ ) relative to those in the PBS group (Fig. 2e). These results indicated that ADSCs partially ameliorated the histological signatures and immunogenic markers of AD.

\section{ADSCs decrease the expression of IL-4R and Th17-associated factors in AD skin}

Because $\mathrm{AD}$ pathogenesis involves dysregulation of multiple types of Th cells, qPCR was performed to detect the expression of inflammatory cytokines associated with Th2 (IL-13, IL-4, and IL-4R), Th17 (IL-17A, CCL20, and MMP12), and Th1 (TNF- $\alpha$ and IFN- $\gamma$ ) cells. The expression of the aforementioned cytokines were found markedly upregulated in the PBS group relative to that in the normal control (IL-13, $p<0.05$; IL-4, $p<0.05$; IL-4R, $p<0.0001$; IL-17A, $p<0.0001$; CCL20, $p<0.005$; MMP12, $p<0.001$; IFN- $\gamma, p<0.0001$; and TNF- $\alpha, p<0.01$ ) (Fig. $3 \mathrm{a}-$ h). Compared with the PBS group, the expression of IL-4R and Th17-associated factors was significantly downregulated in the mice that received the ADSCs treatment (IL4-R, $p<0.0001$; IL-17A, $p<0.0001$; CCL20, $p<0.05$; and MMP12, $p<0.05$ ) (Fig. 3c-f) and cortisone treatment (IL-4R, $p<0.0001$; IL-17A, $p<0.0001$; and CCL20, $p<0.05$ ) (Fig. 3c-e). Additionally, IFN $-\gamma$ (Fig. 3g) and TNF- $\alpha$ (Fig. $3 \mathrm{~h}$ ) expression was slightly decreased in the ADSC- and cortisone-treated groups relative to the PBS-treated group, although the differences were not statistically significant. The expression of IL-13 (Fig. 3a) and IL-4 (Fig. 3b) was slightly increased in the ADSC-treated group as compared with the PBS-treated group, but there was no statistical significance (Fig. 3a, b). These results suggested that ADSCs treatment inhibited the expression of AD-related inflammatory factors.

\section{ADSCs normalize elevation of the IL-17 signaling pathway in OVA-induced AD skin lesions}

To determine the mechanisms by which ADSCs improve AD symptoms, skin lesions from the normal control, PBS, ADSC, and cortisone groups were analyzed using high-throughput RNA-sequencing analysis. Principal component analysis (PCA) showed that the ADSC group was clearly separated from the normal control, PBS, and cortisone groups (Fig. 4a, green circles), suggesting that ADSCs regulate a different gene expression program in $\mathrm{AD}$ restoration. According to the established thresholds, 4771 DEGs were identified from the skin specimens of the four groups (Fig. 4b), with 2965 DEGs between the PBS and normal control groups, 2641 DEGs between the ADSC and PBS groups, 933 DEGs between the cortisone and PBS groups, and 1204 DEGs between the ADSC and cortisone groups (Fig. 4c).

To determine the specific biological processes and signaling pathways involved in the repair of AD by ADSCs, GO and KEGG analyses were performed on the upregulated DEGs between the PBS and normal control groups. GO results showed that the top 10 terms for biological process (BP), cellular component (CC), and molecular function (MF) were mostly related to epidermis hyperplasia, leukocyte migration, and cytokine-related activities (Fig. 5a). Compared with the normal control group, KEGG analysis showed a significant change in the IL-17 signaling pathway in the PBS group, suggesting that Th17 cells were activated after OVA sensitization (Fig. 5b).

Subsequently, GO and KEGG analyses were conducted on the downregulated DEGs between the ADSC and PBS groups and between the cortisone and PBS groups. GO results showed that ADSCs and cortisone treatments downregulated the expression of genes mainly involved in leukocyte activities, bacterium response, and cytokinerelated activities (Fig. 5c), indicating the alleviation of AD-related inflammatory responses after treatment. KEGG analysis showed a significant change in the IL-17 signaling pathway between the ADSC and PBS groups (ranked ninth) and between the cortisone and PBS groups (ranked second) (Fig. 5d), suggesting that ADSCs effectively suppress activation of Th17 cells, similar to cortisone treatment.

\section{ADSCs suppress the proliferation and activation of Th 17 cells in vitro}

To identify the mechanism associated with ADSC-mediated inhibition of Th17 cell activation, a direct co-culture of ADSCs and Th17 cells was conducted. After $72 \mathrm{~h}$ of incubation, fewer $\mathrm{T}$ cell receptor-activated $\mathrm{T}$ cell clusters, indicators of $\mathrm{T}$ cell proliferation, were observed in the coculture group relative to those observed in monocultured Th17 cells (Fig. 6a). Additionally, monocultured Th17 

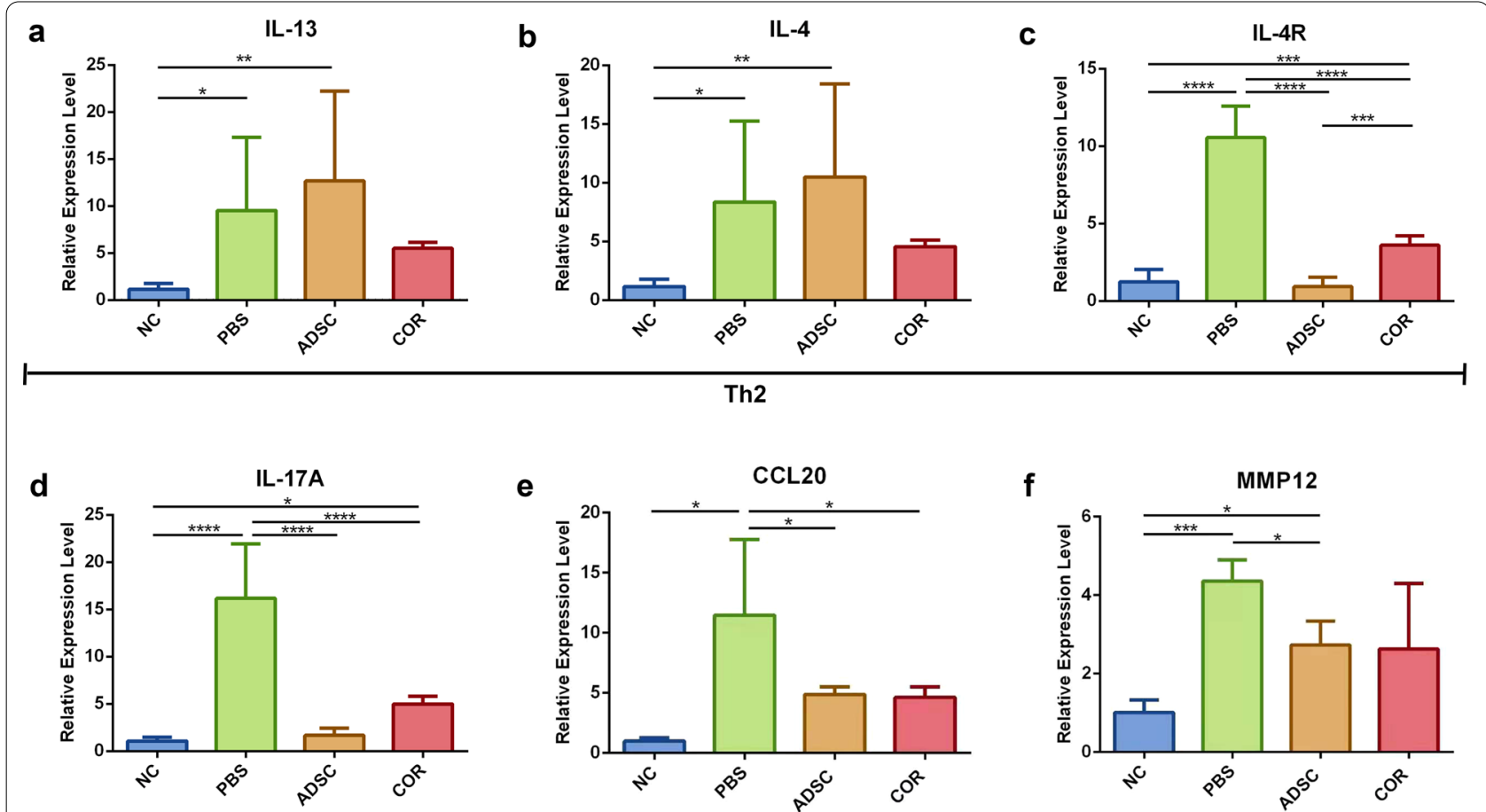

Th2

1

e

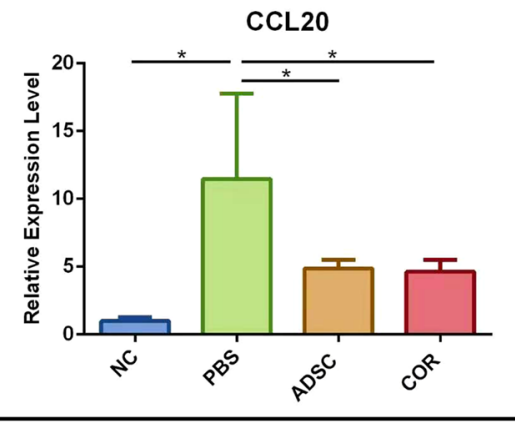

$\mathbf{f}$

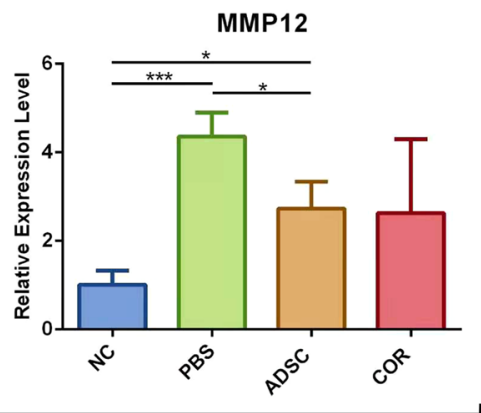

Th17

g

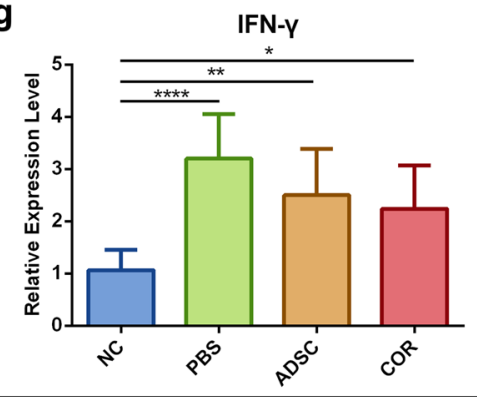

h

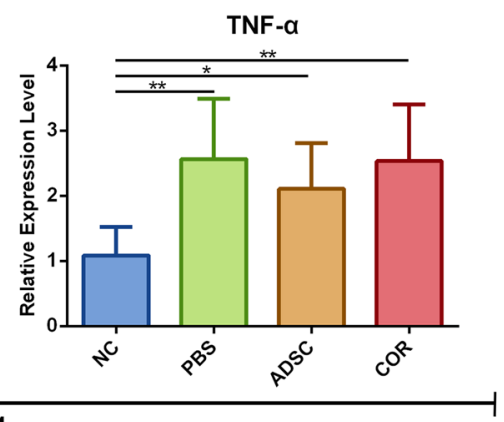

Th1

Fig. 3 Effect of ADSCS on gene expression level of proinflammatory cytokines in OVA-induced AD mice. Relative gene expression levels of $\mathbf{a} I L-13, \mathbf{b}$

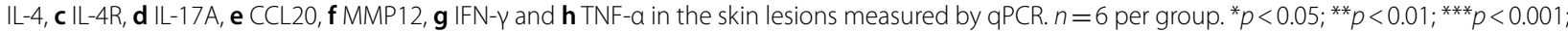
${ }^{* * *} p<0.0001$. NC, normal control; PBS, phosphate-buffered saline; ADSC, adipose-derived stem cell; AD, atopic dermatitis; OVA, ovalbumin; qPCR, quantitative real-time polymerase chain reaction; COR, cortisone; IL, interleukin; IL-4R, IL-4 receptor; CCL20, C-C motif chemokine ligand 20; MMP12, matrix metallopeptidase 12; IFN- $\gamma$, interferon-gamma; TNF-a, tumor necrosis factor-alpha

cells proliferated to $3.774 \pm 0.1297 \times 10^{6}$ in $72 \mathrm{~h}$, whereas only $0.6310 \pm 0.1465 \times 10^{6} \mathrm{Th} 17$ cells were counted in the co-culture group, which was also fewer than the initial cell number $\left(2 \times 10^{6}\right)(p<0.0001$, Fig. 6b). Correspondingly, the expression levels of IL-17A and RORYT, the master transcription factor associated with Th17 cell differentiation, were significantly reduced under the coculture conditions (IL-17A, $p<0.01$; and ROR $\gamma \mathrm{T}, p<0.01$ ) (Fig. 6c, e). Furthermore, IL-17F expression was reduced in co-cultured Th17 cells, although there was no significant difference relative to that in monocultured Th17 cells (Fig. 6d). These results indicated that ADSCs treatment suppressed the proliferation and activation of Th17 cells.

As shown in Fig. 7a, no obvious morphological differences were observed between co-cultured and monocultured ADSCs. Furthermore, the expression of PD-L1, TGF- $\beta$, and PGE2, which reportedly participate in MSC-specific immunomodulatory effects [30, 31], was significantly upregulated in the co-cultured ADSCs as compared with their expression in monocultured 

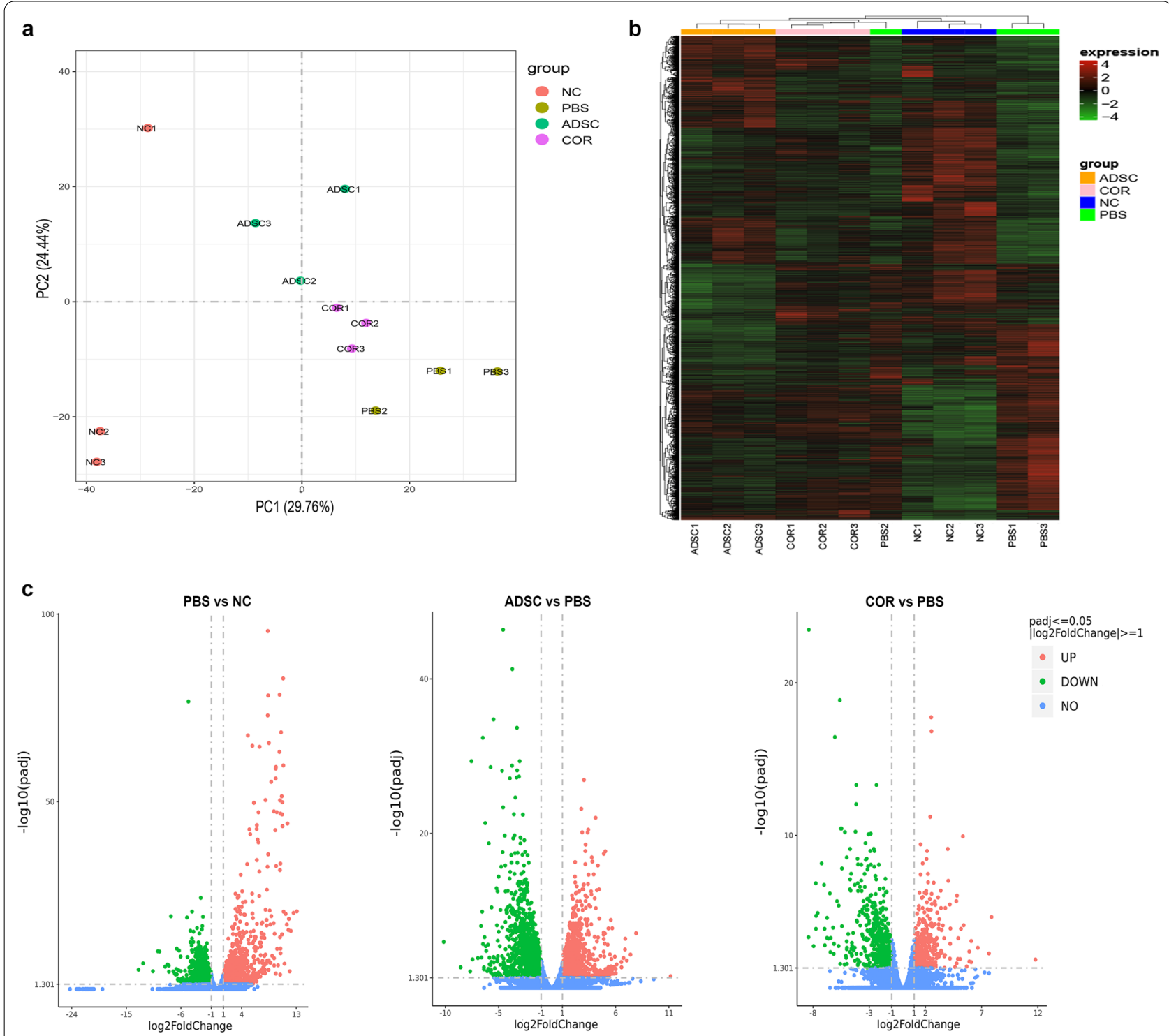

Fig. 4 RNA sequencing of mice dorsal skin samples. a PCA of dorsal skin samples in the NC, PBS, ADSC, and COR groups. b Heat maps of DEGs between the NC, PBS, ADSC, and COR groups. c Volcano plots of DEGs between the PBS and NC groups (left), the ADSC and PBS groups (middle), and the COR and PBS groups (right); $n=3$ per group. NC, normal control; PBS, phosphate-buffered saline; ADSC, adipose-derived stem cell; COR, cortisone; PCA, principal component analysis; padj, adjusted $p$ value

ADSCs (PD-L1, $p<0.05$; TGF- $\beta, p<0.05$; PGE2, $p<0.05)$ (Fig. 7b-d).

\section{Discussion}

In this study, subcutaneous administration of ADSCs was found ameliorated OVA-induced murine AD, potentially through downregulation of IL-17 secretion by Th17 cells. The delivery methods of MSCs in AD models mainly include subcutaneous and intravenous injections [22, 32]. Although a previous study reported that ADSCs have homing effects to the injured tissues after intravenous injection [33], another report indicated that this administration route would lead to low viability of stem cells because of pulmonary interception [34]. Additionally, another report demonstrated that local injection of ADSCs resulted in higher viability than intravenous injection [24]. Therefore, in the present study, ADSCs were administrated directly to lesion sites by subcutaneous injection and successful relief of $\mathrm{AD}$ symptoms was observed.

IgE-mast cells interactions are known to play a pivotal role in many allergic and inflammatory responses 


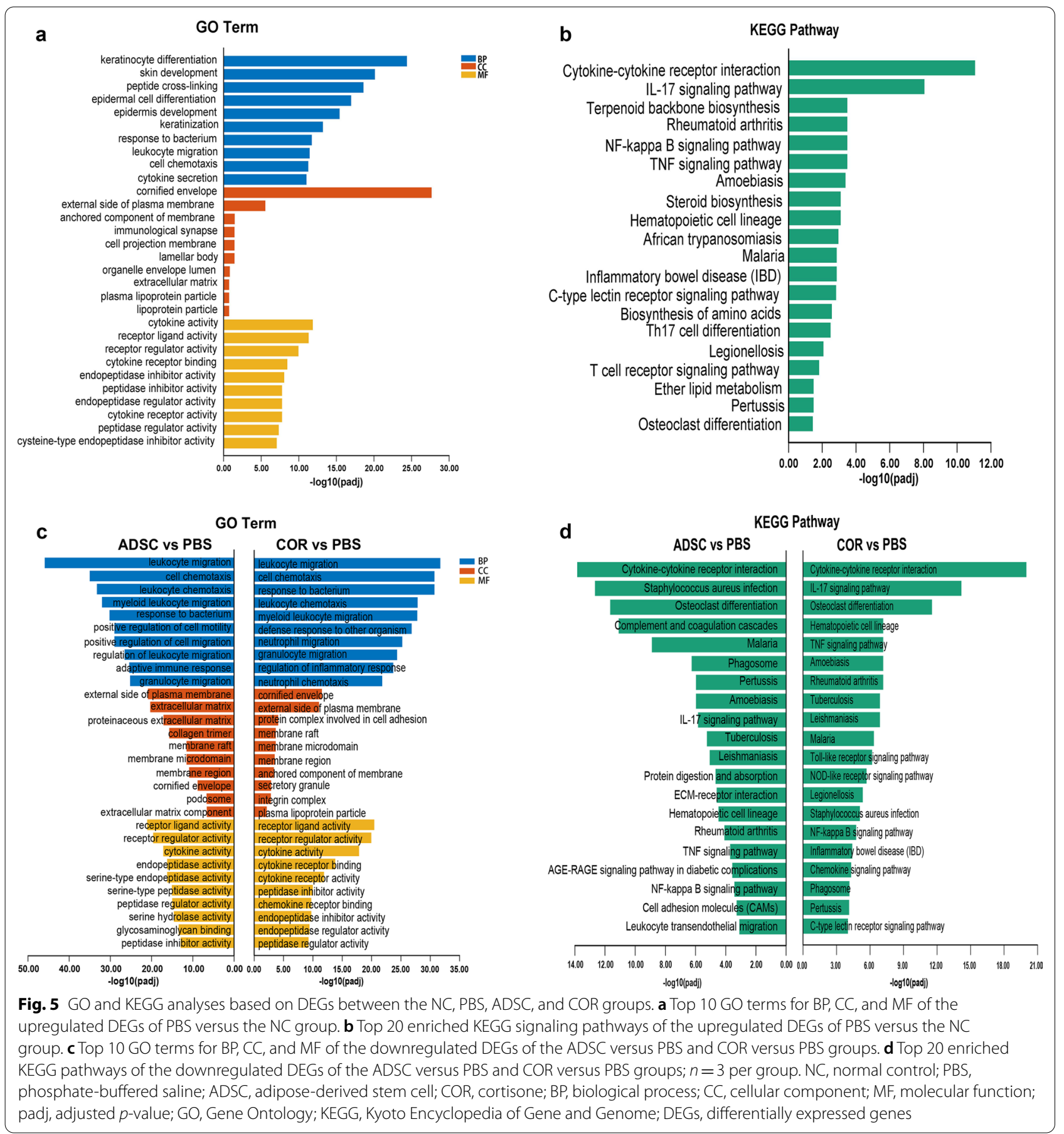

[35, 36]. Mast cells activated by IgE degranulate to release various proinflammatory mediators and contribute to the persistence of $\mathrm{AD}$ symptoms [37, 38]. Ando et al. [39] reported that inhibition of mast cell activities leads to the amelioration of $A D$, whereas increased mast cell activities aggravate AD symptoms. In the present study, significantly lower numbers of infiltrated mast cells and serum IgE levels were observed following ADSCs treatment, suggesting an inhibitory effect of the ADSCs on mast cells recruitment and local allergic responses. This inhibitory effect of MSCs on mast cells was also confirmed in a previous study using dinitrochlorobenzene-induced $\mathrm{AD}$ BALB/c mice treated with human-derived ADSCs and in OVA-induced $B A L B / c$ mice treated with superoxide dismutase 3-transduced MSCs [40]. A recent study 
a

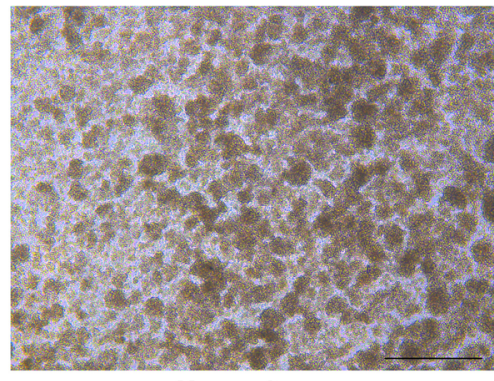

Monoculture

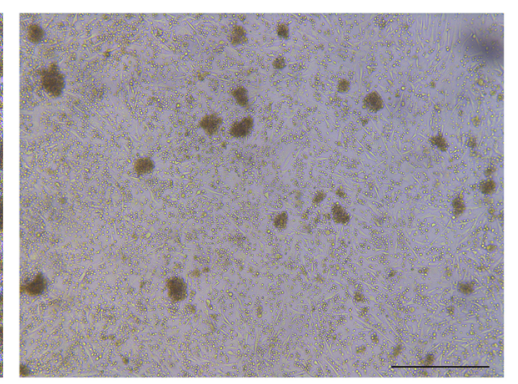

Co-culture

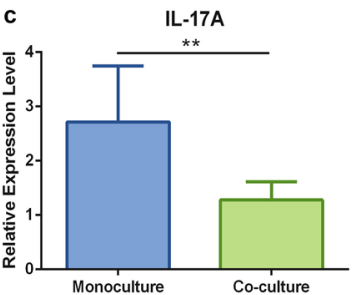

d

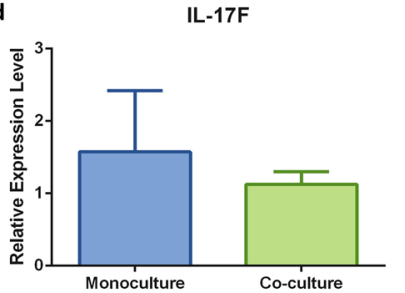

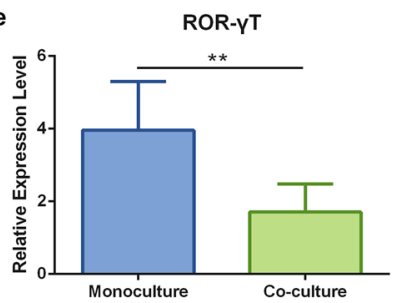

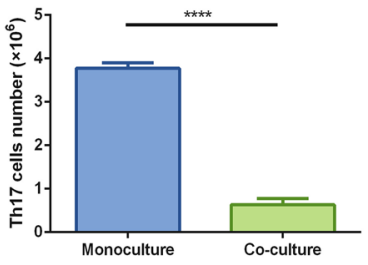

f

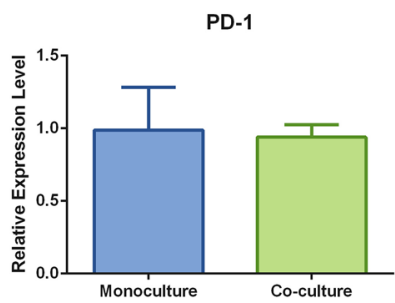

Fig. 6 Effect of ADSCs on proliferation and activation of Th17 cells. a Representative photomicrographs of the monocultured (left) and co-cultured (right) Th17 cells after $72 \mathrm{~h}$ of incubation. Scale bar $=500 \mu \mathrm{m}$. b Cell count of the monocultured and co-cultured Th17 cells after $72 \mathrm{~h}$ of incubation. Relative gene expression levels of $\mathbf{c} I \mathrm{~L}-17 \mathrm{~A}, \mathbf{d} \mathrm{IL}-17 \mathrm{~F}$, and $\mathbf{e} \mathrm{ROR}$ T in the monocultured and co-cultured Th17 cells determined by qPCR. $n=5$ per group. * $p<0.05 ;{ }^{* *} p<0.01$; ${ }^{* * *} p<0.0001$. ADSCs, Adipose-derived stem cells; interleukin, IL; RORYT, RAR-related orphan receptor gamma T; qPCR, quantitative real-time polymerase chain reaction

reported that the number of mast cells and serum $\operatorname{IgE}$ levels were nearly threefold higher in the control group relative to those in AD model mice treated with human umbilical cord blood-derived MSCs [41]. Additionally, Park et al. [21] reported a nearly 3.2-fold decrease in the number of mast cells in skin samples from AD mice treated with autologous ADSCs relative to that in control mice. In the present study, the number of mast cells and serum IgE levels were observed $\sim 1.5$ - and 1.3-fold higher in PBS-treated AD mice, respectively, relative to those in ADSC-treated mice. The authors speculated that the differences in therapeutic effectiveness and mast cell populations in response to stem cells treatment might be attributed to the diversity in cell lines and animal models.

As a mediator for IL-4 and IL-13 acting on downstream inflammatory cells, IL-4R complex participate in multiple signaling pathways that related to $\mathrm{AD}$ immune dysregulation [42, 43].Yun et al. [44] reported treating 2,4-dinitrochlorobenzene (DNCB)-induced AD mice with echinochrome A (an anti-inflammatory and antioxidative drug), revealing that echinochrome A appeared to suppress the expression and secretion of the proinflammatory cytokine IL-4 and IL-13. A recent study showed that the clinical features of experimental atopic dermatitis are driven by IL- 4 and IL- 13 signaling via IL-4R and highlighted that IL-4R might serve as a potent therapeutic target for the treatment of $\mathrm{AD}$ and other allergic diseases [45]. In the present study, ADSCs treatment downregulated the expression of IL-4R rather than IL-4 and IL-13, indicating that ADSCs might inhibit Th2mediated inflammation by suppressing IL-4R-specific activity in various downstream inflammatory cells but not by directly decreasing the production of Th2-related cytokines. However, the underlying mechanisms remain to be clarified.

Recent studies indicate that Th17 cells are profoundly involved in the pathogenesis of certain skin disorders and autoimmune diseases [46-48]. Consistent with previous studies [49-51], the present study identified increases in the expression of the general inflammation marker MMP12 and the Th17 marker CCL20 in AD skin lesions, whereas ADSC treatment reversed these changes. Cytokines secreted by Th17 cells were reported to stimulate CCL20 expression by keratinocytes, which in turn recruits more Th17 cells and creates a positive feedback loop to maintain the inflammatory state in skin lesions [52, 53]. Notably, the observed reduction in CCL20 expression in ADSC-treated AD skin indicated attenuation of the feedback loop, possibly through inhibition of Th17-related cytokine production by ADSCs. IL-17, a key cytokine for Th17 cells, reportedly participates in allergen-specific immune responses [54, 55], exhibits increased expression in skin trauma and skin barrier dysfunction-associated diseases [56], regulates epidermal cell proliferation conditions and skin 


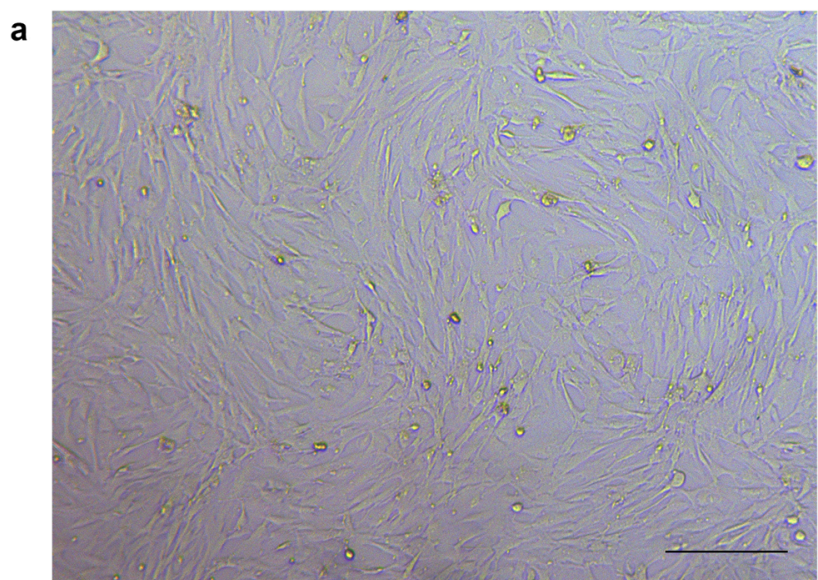

Monoculture

b

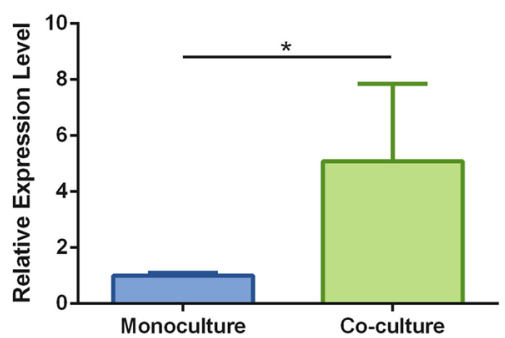

c

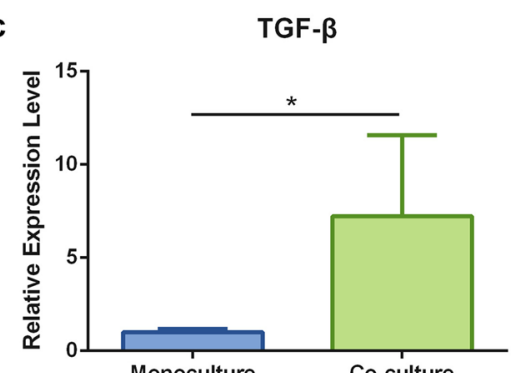

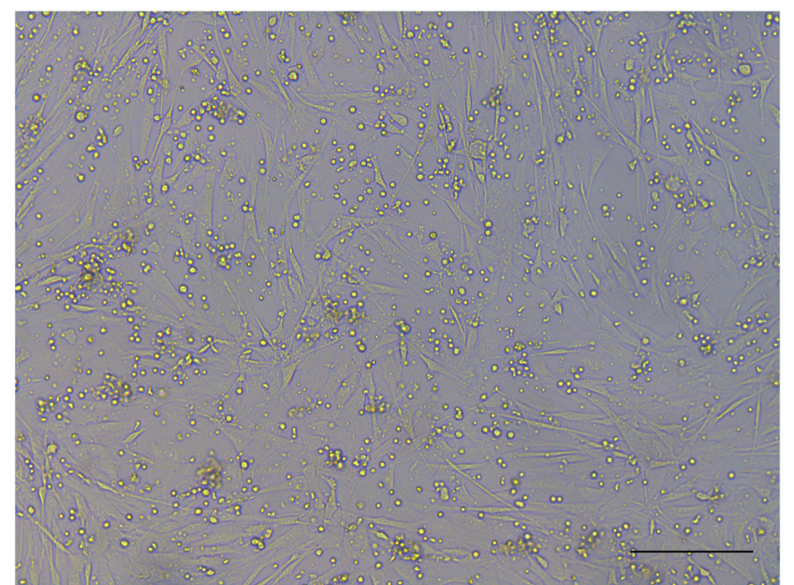

Co-culture d

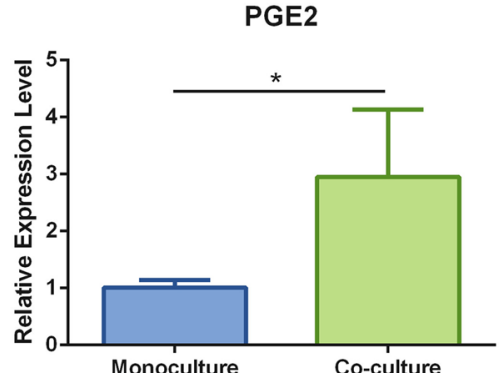

Fig. 7 Gene expression level of PD-L1, TGF- $\beta$, and PGE2 in ADSCs. a Representative photomicrographs of the monocultured (left) and co-cultured (right) ADSCs after $72 \mathrm{~h}$ of incubation. Scale bar $=200 \mu \mathrm{m}$. Relative gene expression levels of $\mathbf{b}$ PD-L1, c TGF- $\beta$, and $\mathbf{d}$ PGE2 in the monocultured and co-cultured Th17 cells determined by qPCR. $n=5$ per group. ${ }^{*} p<0.05$. ADSCs, Adipose-derived stem cells; PD-L1, programed death ligand $1 ;$ TGF- $\beta$, transforming growth factor-beta; $\mathrm{PGE}$, prostaglandin $\mathrm{E2}$; $\mathrm{qPCR}$, quantitative real-time polymerase chain reaction

thickening [57]. Given the proinflammatory properties, IL-17 was subsequently investigated. A previous study reported that application of the anti-inflammatory agent artesunate significantly decreased the expression of IL-17 and improved the histopathological symptoms in DNCB-induced AD mice [58]. Studies on the interaction between MSCs and Th17 cells showed that MSCs and their exosomes treatment can significantly reduce the percentage of Th17 cells and the expression of IL-17 in experimental autoimmune uveitis [59] and Sjögren's syndrome [60] models. The present results revealed that the mRNA expression of IL-17 in skin samples was effectively inhibited in ADSC-treated mice relative to that in PBS-treated mice. Moreover, RNAsequencing analysis identified a remarkable downregulation of IL-17 signaling pathways in ADSC-treated mice, indicating that the therapeutic effect of ADSCs on AD may be attributable to downregulating IL-17 secretion by Th17 cells. A recent study demonstrated that Th17-mediated skin inflammation facilitates mast cell aggregation [61]. Therefore, the downregulation of
Th17 signaling in skin lesions of ADSC-treated mice might partially explain observed decreases in mast cell aggregation relative to that in PBS-treated mice in the present study.

Although the mechanisms associated with the immunosuppressive effect of MSCs on Th17 cells have not been fully elucidated, several processes have been reported recently, including dependence on cell-cell contact-based inhibition and the production of soluble factors [62]. In the present study, ADSCs were found to exert a strong immunosuppressive effect on Th17 cells in co-culture assay. PD-L1 is expressed on the cytomembrane of MSCs and plays an important role in the negative regulation of immune responses [30, 63]. A previous study reported that co-culture of bone marrow-derived MSCs with Th17 lymphocytes led to a significantly increase in PD-L1 expression on the surface of MSCs, which inhibited the proliferation of Th17 cells, with the latter effect reversed by PD-L1-neutralizing antibodies [64]. The present study showed significant accumulation of PD-L1 during co-culture, 
indicating that inhibition of Th17 signaling by ADSCs might be partially attributable to cellular contact with Th17 cells via PD-L1. Additionally, MSC-derived PGE2 and TGF- $\beta$ reportedly play a significant role in regulating multiple immune suppressive effects $[31,65,66]$. Upon exposure to Th17-skewing conditions, MSCderived PGE2 inhibits IL-17A secretion through via cell contact-dependent mechanism [31, 67]. To assessed the immunoregulatory effects of secretory factors produced by ADSCs, Vasilev et al. [68] co-cultured ADSC-conditioned medium with peripheral blood mononuclear cells from rheumatoid arthritis patients, with the coculture system demonstrating an increase in the Treg/ Th17 ratio, as well as in the expression of TGF- $\beta$ and a decrease in IL-17 production. In the present study, the co-culture ADSCs were found contained higher levels of $\mathrm{PGE}_{2}$ and TGF- $\beta$, relative to the monocultured cells, which might explain the immunosuppressive effect of ADSCs on Th17 cells. Collectively, the present study demonstrated that ADSCs exerted an immunosuppressive effect on Th17 cells, which might be attributable to both cell-cell contact inhibition and secretion of immunosuppressive cytokines; however, further study is required to clarify the exact mechanisms.

Therapeutic options for AD remain limited, in part because currently available models do not adequately capture all immune and barrier features of human $\mathrm{AD}$ skin [69-71], with OVA-induced and NC/Nga mice being one of the best animal models available [72]. However, there are diverse of immune responses reported between experimental AD studies, with these differences possibly resulting from the use of different animal models and methods [72-74]. Th17 signaling has been reported in various autoimmune disease. In particular, recent studies have suggested increased Th17 activation in Asian AD patients, where the percentage of Th17 signaling significantly correlated with AD severity [75-78]. Therefore, the present study provides some novel insights that broadens the overall understanding of and therapeutic approach to Th17 signaling in AD.

This study has some limitations. First, this study employed an OVA-induced AD mouse model. The use of more reliable animal models (i.e., xenografted or bioengineered skin-humanized mice) capable of capturing additional AD features might be desirable. Second, a recent study demonstrated that different MSC lines have different immunomodulatory properties [79]; therefore, a comparison of therapeutic effects between different MSC lines on AD mouse skin would deepen our understanding regarding the therapeutic mechanisms of AD treated with MSCs. Third, the therapeutic effects of stem cells are mainly attributable to their tissue regenerative capacity and immunomodulatory ability; however, in this study, only the immunomodulatory ability of ADSCs on AD was investigated. Further studies to clarify the tissue regenerative capacity of ADSCs on AD are required.

\section{Conclusions}

MSC-based therapy is a promising and potent therapeutic approach to human allergic diseases, particularly AD. In this study, subcutaneous injection of ADSCs ameliorated AD by downregulating IL-17 secretion by Th17 cells in an OVA-induced mouse model. Additionally, this study employed RNA-sequencing technology to offer a comprehensive perspective on pathological changes in ADSC-treated AD skin. These findings can expand the knowledge concerning the mechanisms of MSC-based therapy for AD and offer insight into novel treatment strategies for allergic diseases using cell therapy. However, the systemic nature of AD indicates that systemic therapies are necessary to manage this disease. Therefore, further research should focus on developing multifaceted treatment strategies for $A D$, including both systemic and topical therapies. Furthermore, given the differences between animal models and humans, the therapeutic effect of ADSCs on human $\mathrm{AD}$ should be demonstrated via clinical studies in the future.

\section{Abbreviations \\ MSCs: Mesenchymal stem cells; AD: Atopic dermatitis; ADSCs: Adipose- derived stem cells; OVA: Ovalbumin; Th: Helper T; PBS: Phosphate-buffered saline; PBS+: PBS supplemented with 1\% penicillin/streptomycin; SVF: Stromal vascular fraction; DMEM: Dulbecco's modified Eagle's medium; FBS: Fetal bovine serum; DMEM-low glucose+: DMEM-low glucose supplemented with $10 \% \mathrm{FBS}$ and $1 \%$ penicillin/streptomycin; $\mathrm{CO}_{2}$ : Carbon dioxide; NC: Normal control; COR: Cortisone; H\&E: Hematoxylin and eosin; TB: Toluidine Blue; IgE: Immunoglobulin E; CDNA: Complementary DNA; PCR: Polymerase chain reac- tion; DEGs: Differentially expressed genes; FC: Fold change; padj: Adjusted $p$ value; GO: Gene Ontology; KEGG: Kyoto Encyclopedia of Gene and Genome; RPMI: Roswell Park Memorial Institute; RPMI-1640+: RPMI-1640 supplemented with 10\% FBS, 2 mM L-glutamine and 1\% penicillin/streptomycin; qPCR: Quan- titative real-time polymerase chain reaction; IL: Interleukin; IL-4R: IL-4 receptor; CCL20: C-C motif chemokine ligand 20; MMP12: Matrix metallopeptidase 12; IFN- $\gamma$ : Interferon-gamma; TNF-a: Tumor necrosis factor-alpha; ROR T: RAR- related orphan receptor gamma T; PD-L1: Programed death ligand 1; TGF- $\beta$ : Transforming growth factor-beta; PGE2: Prostaglandin E2; SD: Standard devia- tion; PCA: Principal component analysis; BP: Biological process; CC: Cellular component; MF: Molecular function; Treg: Regulatory T.}

\section{Supplementary Information}

The online version contains supplementary material available at https://doi. org/10.1186/s13287-022-02774-7.

Additional file 1: Table S1. Primer-probe sequences for the quantitative real-time polymerase chain reaction.

Additional file 2: Fig. S1. Multi-lineage differentiation of ADSCs. (a) Alcian Blue, (b) Alizarin Red, and (c) Oil Red O staining of ADSCs cultured in chondrogenic, osteogenic, and adipogenic differentiation mediums, 
respectively. Arrows indicate areas that were typically positive for each staining. Scale bar $=200 \mu \mathrm{m}$. ADSCs, Adipose-derived stem cells.

\section{Acknowledgements}

Not applicable.

\section{Authors' contributions}

JG carried out the experiments, data analyses and manuscript writing. YL participated in the in vivo experiments. FL and JF designed the study and revised the manuscript. All authors read and approved the final manuscript.

\section{Funding}

This study was supported by the National Nature Science Foundation of China $(81601702,81671931,81701920,81801933,82102350,82002058)$ and the Natural Science Foundation of Guangdong Province of China (2017A030313900).

\section{Availability of data and materials}

The datasets used and/or analyzed during the current study are available from the corresponding author on reasonable request.

\section{Declarations}

\section{Ethics approval and consent to participate}

All animal procedures have been approved by the Institutional Animal Care and Use Committee of Nanfang Hospital (Ethical Number: NFYY-2020-0294).

\section{Consent for publication}

Not applicable.

\section{Competing interests}

The authors declare that they have no competing interests.

Received: 26 October 2021 Accepted: 31 January 2022 Published online: 07 March 2022

\section{References}

1. Langan SM, Irvine AD, Weidinger S. Atopic dermatitis. Lancet. 2020;396(10247):345-60. https://doi.org/10.1016/50140-6736(20) 31286-1.

2. Lloyd Lavery A, Solman L, Grindlay DJC, Rogers NK, Thomas KS, Harman KE. What's new in atopic eczema? An analysis of systematic reviews published in 2016. Part 2: epidemiology, aetiology and risk factors. Clin Exp Dermatol. 2019;44(4):370-5. https://doi.org/10.1111/ced.13853.

3. Hadi HA, Tarmizi Al, Khalid KA, Gajdács M, Aslam A, Jamshed S. The epidemiology and global burden of atopic dermatitis: a narrative review. Life. 2021;11(9):936. https://doi.org/10.3390/life11090936.

4. Barbarot S, Auziere S, Gadkari A, Girolomoni G, Puig L, Simpson EL, et al. Epidemiology of atopic dermatitis in adults: results from an international survey. Allergy. 2018;73(6):1284-93. https://doi.org/10.1111/all.13401.

5. Apfelbacher CJ, Diepgen TL, Schmitt J. Determinants of eczema: population-based cross-sectional study in Germany. Allergy. 2011;66(2):206-13. https://doi.org/10.1111/j.1398-9995.2010.02464.x.

6. Irvine AD, McLean WH, Leung DY. Filaggrin mutations associated with skin and allergic diseases. N Engl J Med. 2011;365(14):1315-27. https:// doi.org/10.1056/NEJMra1011040.

7. Li Q, Yang Y, Chen R, Kan H, Song W, Tan J, et al. Ambient air pollution, meteorological factors and outpatient visits for eczema in Shanghai, China: a time-series analysis. Int J Environ Res Public Health. 2016;13(11):1106. https://doi.org/10.3390/ijerph13111106.

8. Mahdavinia M, Rasmussen HE, Botha M, Binh Tran TD, Van den Berg $J$ J, Sodergren $\mathrm{E}$, et al. Effects of diet on the childhood gut microbiome and its implications for atopic dermatitis. J Allergy Clin Immunol. 2019;143(4):1636-7. https://doi.org/10.1016/j.jaci.2018.11.034.

9. Yoshida Y, Hayakawa K, Fujishiro M, Ikeda K, Tsushima H, Hirai T, et al. Social defeat stress exacerbates atopic dermatitis through downregulation of DNA methyltransferase 1 and upregulation of $\mathrm{C}-\mathrm{C}$ motif chemokine receptor 7 in skin dendritic cells. Biochem Biophs Res Commun. 2020;529(4):1073-9. https://doi.org/10.1016/j.bbrc.2020.06.157.

10. Leung DYM, Guttman-Yassky E. Deciphering the complexities of atopic dermatitis: shifting paradigms in treatment approaches. J Allergy Clin Immunol. 2014;134(4):769-79. https://doi.org/10.1016/j.jaci.2014.08.008.

11. Brunner PM, Guttman-Yassky E, Leung DYM. The immunology of atopic dermatitis and its reversibility with broad-spectrum and targeted therapies. J Allergy Clin Immunol. 2017;139(4):S65-76. https://doi.org/ 10.1016/j.jaci.2017.01.011.

12. Guttman-Yassky E, Nograles KE, Krueger JG. Contrasting pathogenesis of atopic dermatitis and psoriasis_-part II: immune cell subsets and therapeutic concepts. J Allergy Clin Immunol. 2011;127(6):1420-32. https://doi.org/10.1016/j.jaci.2011.01.054.

13. Suarez-Farinas M, Dhingra N, Gittler J, Shemer A, Cardinale I, de Guzman SC, et al. Intrinsic atopic dermatitis shows similar TH2 and higher TH17 immune activation compared with extrinsic atopic dermatitis. J Allergy Clin Immunol. 2013;132(2):361-70. https://doi.org/10.1016/j. jaci.2013.04.046.

14. Kennedy K, Heimall J, Spergel JM. Advances in atopic dermatitis in 2017. J Allergy Clin Immunol. 2018;142(6):1740-7. https://doi.org/10. 1016/j.jaci.2018.10.012.

15. Saeki H, Nakahara T, Tanaka A, Kabashima K, Sugaya M, Murota H, et al. Clinical practice guidelines for the management of atopic dermatitis 2016. J Dermatol. 2016;43(10):1117-45. https://doi.org/10.1111/13468138.13392.

16. Silverberg NB, Duran-McKinster C. Special considerations for therapy of pediatric atopic dermatitis. Dermatol Clin. 2017;35(3):351-63. https:// doi.org/10.1016/j.det.2017.02.008.

17. Markov A, Thangavelu L, Aravindhan S, Zekiy AO, Jarahian M, Chartrand $M S$, et al. Mesenchymal stem/stromal cells as a valuable source for the treatment of immune-mediated disorders. Stem Cell Res Ther. 2021;12(1):192. https://doi.org/10.1186/s13287-021-02265-1.

18. Naji A, Eitoku M, Favier B, Deschaseaux F, Rouas-Freiss N, Suganuma N. Biological functions of mesenchymal stem cells and clinical implications. Cell Mol Life Sci. 2019;76(17):3323-48. https://doi.org/10.1007/ s00018-019-03125-1.

19. Tavakoli S, Ghaderi Jafarbeigloo HR, Shariati A, Jahangiryan A, Jadidi F, Jadidi Kouhbanani MA, et al. Mesenchymal stromal cells; a new horizon in regenerative medicine. J Cell Physiol. 2020;235(12):9185-210. https://doi.org/10.1002/jcp.29803.

20. Shin T, Lee B, Choi SW, Shin J, Kang I, Lee JY, et al. Human adipose tissue-derived mesenchymal stem cells alleviate atopic dermatitis via regulation of B lymphocyte maturation. Oncotarget. 2017;8(1):512-22. https://doi.org/10.18632/oncotarget.13473.

21. Park H, Son H, Choi M, Son Y, Kim S, Hong H, et al. Adipose-derived stem cells attenuate atopic dermatitis-like skin lesions in NC/Nga mice. Exp Dermatol. 2019;28(3):300-7. https://doi.org/10.1111/exd.13895.

22. Kim M, Lee SH, Kim Y, Kwon Y, Park Y, Lee HK, et al. Human adipose tissue-derived mesenchymal stem cells attenuate atopic dermatitis by regulating the expression of MIP-2, miR-122a-SOCS1 axis, and Th1/ Th2 responses. Front Pharmacol. 2018;9:1175. https://doi.org/10.3389/ fphar.2018.01175.

23. Na K, Yoo HS, Zhang YX, Choi MS, Lee K, Yi TG, et al. Bone marrowderived clonal mesenchymal stem cells inhibit ovalbumin-induced atopic dermatitis. Cell Death Dis. 2014;5: e1345. https://doi.org/10. 1038/cddis.2014.299.

24. Kim H, Yun J, Shin T, Lee S, Lee B, Yu K, et al. Human umbilical cord blood mesenchymal stem cell-derived PGE2 and TGF- $\beta 1$ alleviate atopic dermatitis by reducing mast cell degranulation. Stem Cells. 2015;33(4):1254-66. https://doi.org/10.1002/stem.1913.

25. Shin TH, Kim HS, Choi SW, Kang KS. Mesenchymal stem cell therapy for inflammatory skin diseases: clinical potential and mode of action. Int J Mol Sci. 2017;18(2):244. https://doi.org/10.3390/ijms18020244.

26. Luo $Y$, Yi $X$, Liang $T$, Jiang $S$, He R, Hu Y, et al. Autograft microskin combined with adipose-derived stem cell enhances wound healing in a full-thickness skin defect mouse model. Stem Cell Res Ther. 2019;10(1):279. https://doi.org/10.1186/s13287-019-1389-4.

27. Eterno V, Zambelli A, Pavesi L, Villani L, Zanini V, Petrolo G, et al. Adipose-derived mesenchymal stem cells (ASCs) may favour breast cancer recurrence via HGF/c-Met signaling. Oncotarget. 2014;5(3):613-33. https://doi.org/10.18632/oncotarget.1359. 
28. Spergel JM, Mizoguchi E, Brewer JP, Martin TR, Bhan AK, Geha RS. Epicutaneous sensitization with protein antigen induces localized allergic dermatitis and hyperresponsiveness to methacholine after single exposure to aerosolized antigen in mice. J Clin Invest. 1998;101(8):1614-22. https://doi.org/10.1172/JCl1647.

29. Flaherty S, Reynolds JM. Mouse Naiive CD4+T cell isolation and in vitro differentiation into T cell subsets. J Vis Exp. 2015;98:52739. https://doi.org/ 10.3791/52739.

30. Kim J, Park M, Kim Y, Ryu K, Lee KH, Cho K, et al. Tonsil-derived mesenchymal stem cells (T-MSCs) prevent Th17-mediated autoimmune response via regulation of the programmed death-1/programmed death ligand-1 (PD-1/PD-L1) pathway. J Tissue Eng Regen Med. 2018;12(2):e1022-33. https://doi.org/10.1002/term.2423.

31. Duffy MM, Pindjakova J, Hanley SA, McCarthy C, Weidhofer GA, Sweeney EM, et al. Mesenchymal stem cell inhibition of T-helper 17 cell- differentiation is triggered by cell-cell contact and mediated by prostaglandin E2 via the EP4 receptor. Eur J Immunol. 2011;41(10):2840-51. https://doi.org/ 10.1002/eji.201141499.

32. Kim HS, Lee JH, Roh KH, Jun HJ, Kang KS, Kim TY. Clinical trial of human umbilical cord blood-derived stem cells for the treatment of moderate-to-severe atopic dermatitis: phase I/lla studies. Stem Cells. 2017:35(1):248-55. https://doi.org/10.1002/stem.2401.

33. Li X, Wang $Q$, Ding L, Wang $Y$, Zhao Z, Mao N, et al. Intercellular adhesion molecule-1 enhances the therapeutic effects of MSCs in a dextran sulfate sodium-induced colitis models by promoting MSCs homing to murine colons and spleens. Stem Cell Res Ther. 2019;10(1):267. https://doi.org/10. 1186/s13287-019-1384-9.

34. Vilalta M, Dégano IR, Bagó J, Gould D, Santos M, García-Arranz M, et al. Biodistribution, long-term survival, and safety of human adipose tissue-derived mesenchymal stem cells transplanted in nude mice by high sensitivity non-invasive bioluminescence imaging. Stem Cells Dev. 2008;17(5):993-1004. https://doi.org/10.1089/scd.2007.0201.

35. Stone KD, Prussin C, Metcalfe DD. IgE, mast cells, basophils, and eosinophils. J Allergy Clin Immunol. 2010;125(2, Supplement 2):S73-80. https:// doi.org/10.1016/j.jaci.2009.11.017.

36. Galli SJ, Tsai M. IgE and mast cells in allergic disease. Nat Med. 2012;18(5):693-704. https://doi.org/10.1038/nm.2755.

37. Kawakami T, Ando T, Kimura M, Wilson BS, Kawakami Y. Mast cells in atopic dermatitis. Curr Opin Immunol. 2009;21(6):666-78. https://doi.org/ 10.1016/j.coi.2009.09.006

38. Mashiko S, Bouguermouh S, Rubio M, Baba N, Bissonnette R, Sarfati M. Human mast cells are major IL-22 producers in patients with psoriasis and atopic dermatitis. J Allergy Clin Immunol. 2015;136(2):351-9. https://doi. org/10.1016/j.jaci.2015.01.033.

39. Ando T, Xiao W, Gao P, Namiranian S, Matsumoto K, Tomimori Y, et al. Critical role for mast cell Stat5 activity in skin inflammation. Cell Rep. 2014;6(2):366-76. https://doi.org/10.1016/j.celrep.2013.12.029.

40. Sah SK, Agrahari G, Nguyen CT, Kim YS, Kang KS, Kim TY. Enhanced therapeutic effects of human mesenchymal stem cells transduced with superoxide dismutase 3 in a murine atopic dermatitis-like skin inflammation model. Allergy. 2018;73(12):2364-76. https://doi.org/10.1111/all. 13594.

41. Park HH, Lee S, Yu Y, Yoo SM, Baek SY, Jung N, et al. TGF- $\beta$ secreted by human umbilical cord blood-derived mesenchymal stem cells ameliorates atopic dermatitis by inhibiting secretion of TNF- $a$ and IgE. Stem Cells. 2020;38(7):904-16. https://doi.org/10.1002/stem.3183.

42. Harb H, Chatila TA. Mechanisms of dupilumab. Clin Exp Allergy. 2019;50(1):5-14. https://doi.org/10.1111/cea.13491.

43. Dubin C, Del DE, Guttman-Yassky E. The IL-4, IL-13 and IL-31 pathways in atopic dermatitis. Expert Rev Clin Immunol. 2021;17(8):835-52. https:// doi.org/10.1080/1744666X.2021.1940962.

44. Yun HR, Ahn SW, Seol B, Vasileva EA, Mishchenko NP, Fedoreyev SA, et al. Echinochrome A treatment alleviates atopic dermatitis-like skin lesions in NC/Nga mice via IL-4 and IL-13 suppression. Mar Drugs. 2021;19(11):622. https://doi.org/10.3390/md19110622.

45. Bitton A, Avlas S, Reichman H, Itan M, Karo-Atar D, Azouz NP, et al. A key role for IL-13 signaling via the type 2 IL-4 receptor in experimental atopic dermatitis. Sci Immunol. 2020;5(44):eaaw2938. https://doi.org/10.1126/ sciimmunol.aaw2938.

46. Albanesi C, Scarponi C, Cavani A, Federici M, Nasorri F, Girolomoni G. Interleukin-17 is produced by both Th1 and Th2 lymphocytes, and modulates interferon-gamma- and interleukin-4-induced activation of human keratinocytes. J Invest Dermatol. 2000;115(1):81-7. https://doi. org/10.1046/j.1523-1747.2000.00041.x.

47. Zheng Y, Danilenko DM, Valdez P, Kasman I, Eastham-Anderson J, Wu J, et al. Interleukin-22, a T(H)17 cytokine, mediates IL-23-induced dermal inflammation and acanthosis. Nature. 2007;445(7128):648-51. https://doi. org/10.1038/nature05505.

48. Esaki H, Brunner PM, Renert-Yuval Y, Czarnowicki T, Huynh T, Tran G, et al. Early-onset pediatric atopic dermatitis is $\mathrm{TH} 2$ but also $\mathrm{TH} 17$ polarized in skin. J Allergy Clin Immunol. 2016;138(6):1639-51. https://doi.org/10. 1016/j.jaci.2016.07.013.

49. He H, Olesen CM, Pavel AB, Clausen ML, Wu J, Estrada Y, et al. Tape-strip proteomic profiling of atopic dermatitis on dupilumab identifies minimally invasive biomarkers. Front Immunol. 2020;11:1768. https://doi.org/ 10.3389/fimmu.2020.01768.

50. Brunner PM, Suárez-Fariñas M, He H, Malik K, Wen H, Gonzalez J, et al. The atopic dermatitis blood signature is characterized by increases in inflammatory and cardiovascular risk proteins. Sci Rep. 2017;7(1):8707-12. https://doi.org/10.1038/s41598-017-09207-z.

51. Khattri S, Brunner PM, Garcet S, Finney R, Cohen SR, Oliva M, et al. Efficacy and safety of ustekinumab treatment in adults with moderate-to-severe atopic dermatitis. Exp Dermatol. 2017;26(1):28-35. https://doi.org/10. 1111/exd.13112.

52. Harper EG, Guo C, Rizzo H, Lillis JV, Kurtz SE, Skorcheva I, et al. Th17 cytokines stimulate CCL20 expression in keratinocytes in vitro and in vivo: implications for psoriasis pathogenesis. J Invest Dermatol. 2009;129(9):2175-83. https://doi.org/10.1038/jid.2009.65.

53. Furue K, Ito T, Tsuji G, Nakahara T, Furue M. The CCL20 and CCR6 axis in psoriasis. Scand J Immunol. 2020;91(3): e12846. https://doi.org/10.1111/ sji.12846.

54. Nakae S, Komiyama Y, Nambu A, Sudo K, Iwase M, Homma I, et al. Antigen-specific T cell sensitization is impaired in IL-17-deficient mice, causing suppression of allergic cellular and humoral responses. Immunity. 2002;17(3):375-87. https://doi.org/10.1016/s1074-7613(02)00391-6.

55. Kolls JK. Oxidative stress in sepsis: a redox redux. J Clin Invest. 2006;116(4):860-3. https://doi.org/10.1172/JCI28111.

56. Sugaya $\mathrm{M}$. The role of Th17-related cytokines in atopic dermatitis. Int J Mol Sci. 2020;21(4):1314. https://doi.org/10.3390/ijms21041314.

57. Wu L, Chen X, Zhao J, Martin B, Zepp JA, Ko JS, et al. A novel IL-17 signaling pathway controlling keratinocyte proliferation and tumorigenesis via the TRAF4-ERK5 axis. J Exp Med. 2015;212(10):1571-87. https://doi.org/ 10.1084/jem.20150204.

58. Bai X, Liu P, Chai Y, Wang Y, Ren S, Li Y, et al. Artesunate attenuates 2, 4-dinitrochlorobenzene-induced atopic dermatitis by down-regulating Th17 cell responses in BALB/C mice. Eur J Pharmacol. 2020;874: 173020. https://doi.org/10.1016/j.ejphar.2020.173020.

59. Mu Y, Xu W, Liu J, Wang Y, Chen J, Zhou Q. Mesenchymal stem cells moderate experimental autoimmune uveitis by dynamic regulating Th17 and Breg cells response. JTissue Eng Regen Med. 2022;16(1):26-35. https:// doi.org/10.1002/term.3259.

60. Li B, Xing Y, Gan Y, He J, Hua H. Labial gland-derived mesenchymal stem cells and their exosomes ameliorate murine Sjögren's syndrome by modulating the balance of Treg and Th17 cells. Stem Cell Res Ther. 2021;12(1):478. https://doi.org/10.1186/s13287-021-02541-0.

61. Cho KA, Park M, Kim YH, Woo SY. Th17 cell-mediated immune responses promote mast cell proliferation by triggering stem cell factor in keratinocytes. Biochem Biophys Res Commun. 2017;487(4):856-61. https://doi. org/10.1016/j.bbrc.2017.04.141.

62. Terraza-Aguirre C, Campos-Mora M, Elizondo-Vega R, Contreras-Lopez RA, Luz-Crawford P, Jorgensen C, et al. Mechanisms behind the immunoregulatory dialogue between mesenchymal stem cells and Th17 cells. Cells. 2020;9(7):1660. https://doi.org/10.3390/cells9071660.

63. Keir ME, Butte MJ, Freeman GJ, Sharpe AH. PD-1 and its ligands in tolerance and immunity. Annu Rev Immunol. 2008;26(1):677-704. https://doi. org/10.1146/annurev.immunol.26.021607.090331.

64. Luz-Crawford P, Noël D, Fernandez X, Khoury M, Figueroa F, Carrión F, et al. Mesenchymal stem cells repress Th17 molecular program through the PD-1 pathway. PLoS ONE. 2012;7(9): e45272. https://doi.org/10.1371/ journal.pone.0045272. 
65. Harris SG, Padilla J, Koumas L, Ray D, Phipps RP. Prostaglandins as modulators of immunity. Trends Immunol. 2002;23(3):144-50. https://doi.org/10. 1016/s1471-4906(01)02154-8.

66. Svobodova E, Krulova M, Zajicova A, Pokorna K, Prochazkova J, Trosan $P$, et al. The role of mouse mesenchymal stem cells in differentiation of naive T-cells into anti-inflammatory regulatory T-cell or proinflammatory helper T-cell 17 population. Stem Cells Dev. 2012;21(6):901-10. https:// doi.org/10.1089/scd.2011.0157.

67. Kalinski P. Regulation of immune responses by prostaglandin E2. J Immunol. 2011;188(1):21-8. https://doi.org/10.4049/jimmunol.1101029.

68. Vasilev G, Ivanova M, Ivanova-Todorova E, Tumangelova-Yuzeir K, Krasimirova E, Stoilov R, et al. Secretory factors produced by adipose mesenchymal stem cells downregulate Th17 and increase Treg cells in peripheral blood mononuclear cells from rheumatoid arthritis patients. Rheumatol Int. 2019;39(5):819-26. https://doi.org/10.1007/s00296-019-04296-7.

69. Martel BC, Lovato P, Baumer W, Olivry T. Translational animal models of atopic dermatitis for preclinical studies. Yale J Biol Med. 2017;90(3):389-402.

70. Guerrero-Aspizua S, Carretero M, Conti CJ, Del RM. The importance of immunity in the development of reliable animal models for psoriasis and atopic dermatitis. Immunol Cell Biol. 2020;98(8):626-38. https://doi.org/ 10.1111/imcb.12365.

71. Nakajima S, Nomura T, Common J, Kabashima K. Insights into atopic dermatitis gained from genetically defined mouse models. J Allergy Clin Immunol. 2019;143(1):13-25. https://doi.org/10.1016/j.jaci.2018.11.014.

72. Ewald DA, Noda S, Oliva M, Litman T, Nakajima S, Li X, et al. Major differences between human atopic dermatitis and murine models, as determined by using global transcriptomic profiling. J Allergy Clin Immunol. 2017;139(2):562-71. https://doi.org/10.1016/j.jaci.2016.08.029.

73. Eyerich K, Brown SJ, Perez WB, Tanaka RJ, Bissonette R, Dhar S, et al. Human and computational models of atopic dermatitis: a review and perspectives by an expert panel of the International Eczema Council. J Allergy Clin Immunol. 2019;143(1):36-45. https://doi.org/10.1016/j.jaci. 2018.10.033.

74. Chan LS, Robinson N, Xu L. Expression of interleukin-4 in the epidermis of transgenic mice results in a pruritic inflammatory skin disease: an experimental animal model to study atopic dermatitis. J Invest Dermatol. 2001;117(4):977-83. https://doi.org/10.1046/j.0022-202x.2001.01484.x.

75. Cesare AD, Meglio PD, Nestle FO. A role for Th17 cells in the immunopathogenesis of atopic dermatitis? I Invest Dermatol. 2008;128(11):2569-71. https://doi.org/10.1038/jid.2008.283.

76. Koga C, Kabashima K, Shiraishi N, Kobayashi M, Tokura Y. Possible pathogenic role of Th17 cells for atopic dermatitis. J Invest Dermatol. 2008;128(11):2625-30. https://doi.org/10.1038/jid.2008.111.

77. Noda S, Suarez-Farinas M, Ungar B, Kim SJ, de Guzman SC, Xu H, et al. The Asian atopic dermatitis phenotype combines features of atopic dermatitis and psoriasis with increased TH17 polarization. J Allergy Clin Immunol. 2015;136(5):1254-64. https://doi.org/10.1016/j.jaci.2015.08.015.

78. Tian X, Liu B, Chen L, Xie Y, Liang J, Yang Y, et al. RNA-Seq identifies marked Th17 cell activation and altered CFTR expression in different atopic dermatitis subtypes in chinese han populations. Front Immunol. 2021;12: 628512. https://doi.org/10.3389/fimmu.2021.628512.

79. Yoo HS, Yi T, Cho YK, Kim WC, Song SU, Jeon MS. Mesenchymal stem cell lines isolated by different isolation methods show variations in the regulation of graft-versus-host disease. Immune Netw. 2013;13(4):133-40. https://doi.org/10.4110/in.2013.13.4.133.

\section{Publisher's Note}

Springer Nature remains neutral with regard to jurisdictional claims in published maps and institutional affiliations.

Ready to submit your research? Choose BMC and benefit from:

- fast, convenient online submission

- thorough peer review by experienced researchers in your field

- rapid publication on acceptance

- support for research data, including large and complex data types

- gold Open Access which fosters wider collaboration and increased citations

- maximum visibility for your research: over $100 \mathrm{M}$ website views per year

At BMC, research is always in progress.

Learn more biomedcentral.com/submissions 